DOI https://doi.org/10.30525/978-9934-26-047-6-35

\title{
DEVELOPMENT OF INSULIN RESISTANCE IN OBESE ADOLESCENTS INTRODUCES GENOME REPROGRAMMING AND CHANGES THE EXPRESSION OF NUMEROUS ENDOPLASMIC RETICULUM STRESS RESPONSIVE GENES
}

\author{
Minchenko D. 0.
}

Candidate of Medical Sciences, Associate Professor, Associate Professor at the Department of Pediatrics

Bogomolets National Medical University

Kyiv, Ukraine

\section{Viletska Yu. M.}

Ph.D.,

Assistant Professor at the Department of Molecular Biology

Palladin Institute of Biochemistry of the National Academy

of Sciences of Ukraine

Kyiv, Ukraine

\section{Minchenko O. H.}

$\mathrm{DrSc}$,

Professor at the Department of Molecular Biology

Palladin Institute of Biochemistry of the National Academy

of Sciences of Ukraine

Kyiv, Ukraine

The development of obesity and its metabolic complications is associated with dysregulation of various intrinsic mechanisms, which control basic metabolic processes through changes in the expression of numerous regulatory genes. Endoplasmic reticulum stress is an impotent component of obesity related metabolic dysregulation as well as the development of insulin resistance and other complications of obesity.

The expression level of different genes as well as microRNA was measured in the blood of obese adolescents without signs of resistance to insulin and with insulin resistance in comparison with the group of relative healthy control individuals without signs of obesity. It was shown that in the blood of obese adolescents with normal insulin sensitivity the expression level of IGFBP4, IGFBP5 and HTRAI genes was down-regulated, but $I G F B P 2$ and IGFBP7 genes up-regulated as compared to control (normal) 
group. At the same time, no significant changes in IGF1 and IGF2 gene expressions in this group of obese adolescents were found. Insulin resistance in obese adolescents led to up-regulation of $I G F 2, I G F B P 2$, and IGFBP7 gene expressions as well as to down-regulation of the expression of $I G F 1$, IGFBP5 and HTRAl genes in the blood in comparison with the obese patients, which have normal insulin sensitivity. Furthermore, the level of IGFBP 4 gene expression was similar in both groups of obese adolescents.

Previously was shown that the expression of genes encoding IGF factors and IGF binding proteins as well as IRS1 are endoplasmic reticulum stress responsible and play important roles in the control of variable metabolic processes $[1-4$, p.3]. It was also shown that obesity is associated with upregulation of the expression level of gene encoding polyfunctional protein insulinase (insulin degrading enzyme, IDE) and down-regulation of pitrilysin metallopeptidase 1 (PITRM1) independently from insulin resistance. Furthermore, suppression of ERN1 signaling pathway of endoplasmic reticulum stress down-regulates the expression of both these genes [5, p. 3]. It was also shown that obesity is associated with upregulation of the expression level of genes encoding $H L A-D R A$ and $H L A$ $D R B 1$, which responsible for immune response, in the blood as compared to control group of relative healthy adolescents. At the same time, significant down-regulation was observed in the expression level of $H L A-G$ gene in the blood of this group of obese adolescents. Furthermore, development of insulin resistance in obese individuals leads to significant down-regulation of $H L A-D R A, H L A-D R B 1, H L A-G$, and $H L A-F$ gene expressions as well as to up-regulation of $N F X 1$ gene as well as microRNA miR-190b in the blood as compared to obese patients without signs of insulin resistance.

Results of this study provide evidence that obesity affects the expression of the subset of genes related to glucose metabolism, cell proliferation and immune response in the blood and that development of insulin resistance in obese adolescents is associated with gene specific changes in the expression of IGF1, IGF2, IGFBP2, IGFBP5, IGFBP7, and HTRA1 genes as well as with strong down-regulation of the expressions of HLA-DRA, HLA-DRB1, $H L A-F$, and $H L A-G$ genes, which may be contribute to the development of obesity complications. It is possible that transcription factor $N F X 1$ and miR$190 \mathrm{~b}$ participate in down-regulation of $H L A-D R A$ gene expression in the blood of obese adolescents with insulin resistance.

\section{References:}

1. Minchenko D.O., Kharkova A.P., Hubenia O.V., Minchenko O.H. Insulin receptor, IRS1, IRS2, INSIG1, INSIG2, RRAD, and BAIAP2 gene expressions in glioma U87 cells with ERN1 loss of function: effect 
of hypoxia and glutamine or glucose deprivation. Endocr. Reg. 2013. 47 (1): 15-26.

2. Minchenko D.O., Kharkova A.P., Karbovskyi L.L., Minchenko O.H. Expression of insulin-like growth factor binding protein genes and its hypoxic regulation in U87 glioma cells depends on ERN1 mediated signaling pathway of endoplasmic reticulum stress. Endocr. Reg. 2015. № 49 (2): 73-83.

3. Minchenko D.O., Kharkova A.P., Halkin O.V., Karbovskyi L.L., Minchenko O.H. Effect of hypoxia on the expression of genes encoded insulin-like growth factors and some related proteins in U87 glioma cells without IRE1 function. Endocr. Reg. 2016. 50 (2): 43-54.

4. Minchenko D.O., Tsymbal D.O., Luzina O.Y., Riabovol O.O., Danilovskyi SV, Minchenko O.H. Silencing of NAMPT leads to upregulation of insulin receptor substrate 1 gene expression in U87 glioma cells. Endocr. Reg. 2020.54 (1): 31-42.

5. Minchenko D.O., Khita O.O., Tsymbal D.O., Danilovskyi S.V., Rudnytska O.V., Halkin O.V., Kryvdiuk I.V., Smeshkova M.V., Yakymchuk M.M., Bezrodnyi BH, Minchenko O.H. Expression of IDE and PITRM1 genes in IRE1 knockdown U87 glioma cells: effect of hypoxia and glucose deprivation. Endocr. Reg. 2020.54 (3): 183-195.

DOI https://doi.org/10.30525/978-9934-26-047-6-36

\section{СУЧАСНИЙ ПЕРЕБІГ ЕНТЕРОВІРУСНОӤ ІНФЕКЦІЇ У ДІТЕЙ}

\section{Онофрійчук О. С.}

кандидат медичних наук,

дочент кафедри дитячих інфекиійних хвороб

Вінницький національний медичний університет імені М. I. Пирогова

Гончарук А. М.

асистент кафедри дитячих інфекиійних хвороб

Вінницький національний медичний університет імені М. І. Пирогова м. Вінниця, Украӥна

В останні роки намітилася чітка тенденція активації ентеровірусної інфекції в світі, про що свідчать постійно зареєстровані в різних країнах світу епідеміологічні підйоми захворюваності й спалахи [1]. 3 одного боку, це пов'язано із зменшенням рівня захворюваності 